Joanna M. Karolczak

\title{
Wykazywanie w poselskim oświadczeniu o stanie majątkowym środków z tytułu świadczenia 500+, alimentów na dzieci oraz przychodu z najmu lokalu mieszkalnego ${ }^{1}$
}

\begin{abstract}
Indication of benefits from the " $500+$ programme", alimony and rental of apartment in the Deputy's financial statement (WAP-635/18): In the author's opinion there is no legal basis for an obligation to indicate benefits from the " $500+$ programme" or alimony in the Deputy's financial statement as "income obtained from employment or other gainful activity or engagement". However, it is not prohibited to indicate them. Alimony for the benefit of a former spouse, children (both minor and adult ones) or other relatives of a Deputy should be disclosed in the point XI (money liabilities valued at over 10.000 PLN) of the financial statement. Income from rented apartment - unless it is a lease carried out within economic activity - shall be considered as "engagement" for the purpose of the financial declaration. It should be disclosed in the Deputy's financial statement.
\end{abstract}

Keywords: alimony, lease, financial statement, Deputy

Słowa kluczowe: alimenty, najem, oświadczenie majątkowe, poseł

Radca prawny, ekspert ds. legislacji BAS; joanna.karolczak@sejm.gov.pl.

\section{Przedmiot opinii}

Przedmiotem opinii jest ustalenie, czy konieczne jest wykazanie w oświadczeniu o stanie majątkowym świadczenia z tytułu 500+, alimentów na dzieci, przychodu z najmu lokalu mieszkalnego (jednorazowa kaucja oraz miesięczny przychód wg umowy).

W opinii został uwzględniony stan prawny na dzień 29 marca 2018 r. Sporządzono ją na podstawie:

- ustawy z 9 maja 1996 r. o wykonywaniu mandatu posła i senatora, Dz.U. 2016, poz. 1510, ze zm.; dalej: u.w.m.p.s.

1 Opinia sporządzona 3 kwietnia 2018 r. na zlecenie Klubu Poselskiego Nowoczesna; BAS-WAP 635/18. 
- ustawy z 11 lutego 2016 r. o pomocy państwa w wychowywaniu dzieci, Dz.U. poz. 195, ze zm.,

- ustawy z 25 lutego 1964 r. - Kodeks rodzinny i opiekuńczy, Dz.U. 2017, poz. 682; dalej: k.r.o.

- ustawy z 21 czerwca 2001 r. o ochronie praw lokatorów, mieszkaniowym zasobie gminy i o zmianie Kodeksu cywilnego, Dz.U. 2016, poz. 1610, ze zm.

\section{Uzasadnienie}

1. Zgodnie z art. 35 ust. 1 u.w.m.p.s. posłowie są obowiązani do złożenia oświadczenia o swoim stanie majątkowym. Oświadczenie to zawiera w szczególności informacje o zasobach pieniężnych (art. 35 ust. 1 pkt 1 u.w.m.p.s. oraz pkt I wzoru oświadczenia „Zasoby pieniężne, środki pieniężne zgromadzone w walucie polskiej”) oraz o dochodach osiąganych z tytułu zatrudnienia lub innej działalności zarobkowej, lub zajęć, z podaniem kwot uzyskiwanych z każdego tytułu (art. 35 ust. 1 pkt 2 ustawy oraz pkt IX wzoru oświadczenia „Inne dochody osiągane z tytułu zatrudnienia lub innej działalności zarobkowej lub zajęć, z podaniem kwot uzyskiwanych z każdego tytułu”).

Nie ulega wątpliwości, że kwoty otrzymane z tytułu świadczenia wychowawczego 500+ zostaną wykazane w sposób pośredni w pkt I „Zasoby pieniężne” (ponieważ w pkt I oświadczenia o stanie majątkowym nie należy wykazywać konkretnych kwot uzyskanych z poszczególnych tytułów), jeśli nadal znajdują się w tych zasobach, w zakresie, w jakim nie zostały one zużyte i przyczyniły się do powstania bądź powiększenia owych zasobów. Nie będzie więc możliwości identyfikacji, czy zgromadzone zasoby pieniężne powstały choćby w części w wyniku otrzymania świadczenia wychowawczego tzw. 500+.

Gdyby „Zasoby pieniężne” wykazywane w pkt I oświadczenia o stanie majątkowym miały być pomniejszane o uzyskane w danym roku świadczenie wychowawcze 500+, konieczne byłoby wyraźne wskazanie takiego sposobu obliczania posiadanych zasobów pieniężnych w przepisie. Można wskazać tytułem przykładu, że ustawodawca przewidział, iż np. świadczenia te są wolne od podatku dochodowego (art. 33 ustawy o pomocy państwa w wychowywaniu dzieci w związku z art. 21 ust. 1 pkt 8 ustawy o podatku dochodowym od osób fizycznych) bądź w jakich sytuacjach nie wlicza się tego świadczenia do dochodu gospodarstwa domowego (np. art. 34, 35, 36, 40 ustawy o pomocy państwa w wychowywaniu dzieci).

Wątpliwość dotyczy natomiast faktu wykazywania świadczenia wychowawczego w pkt IX „Dochody osiąganego z tytułu zatrudnienia lub innej działalności zarobkowej lub zajęć, z podaniem kwot uzyskiwanych z każdego tytułu”. Świadczenie wychowawcze, tzw. 500+, ma na celu częściowe pokrycie wydatków związanych z wychowywaniem dziecka, w tym z opieką nad nim i zaspokoje- 
niem jego potrzeb życiowych. Stanowi ono dochód osób uprawnionych. Jednakże, zdaniem Autorki opinii, nie stanowi dochodu osiąganego z tytułu zatrudnienia, innej działalności zarobkowej ani zajęć, co stanowi istotę art. 35 ust. 1 pkt 1 u.w.m.p.s. oraz pkt IX wzoru oświadczenia. W tym punkcie ujawnia się dochody takie, jak dochody ze stosunku pracy za okres całego roku, renty, emerytury, zasiłki dla bezrobotnych, dochody z działalności gospodarczej i z innej działalności zarobkowej (umowy o dzieło, w tym umowy o prawa autorskie, umowy-zlecenia, umowy komisu), z umowy najmu, dzierżawy ${ }^{2}$, a także diety. Wszystkie te dochody stanowią dochody $\mathrm{z}$ aktywności zawodowej (zarobkowej) lub jej swoisty ekwiwalent (jak np. renta czy zasiłek dla bezrobotnych).

Kwestia ujawniania „innych dochodów” budzi w praktyce składania oświadczeń wątpliwości. Biorąc pod uwage literalne brzmienie tego przepisu, nie byłoby konieczności deklarowania tu rent, emerytur, zasiłku dla bezrobotnych. Jednakże $z$ drugiej strony oświadczenie majątkowe stuży ukazaniu społeczeństwu, z jakich źródeł utrzymuje się osoba publiczna i jakie to sa kwoty. Zatem, na jakim materialnym poziomie egzystuje? W mojej ocenie, zobowiazani do składania oświadczeń majątkowych powinni podać każdy rodzaj własnego dochodu, zarówno podlegajacego opodatkowaniu i składkom, jak i zwolnionego od nich (a więc renty, emerytury, zasiłki dla bezrobotnych, wynagrodzenie, dochody $z$ działalności gospodarczej, najmu, dzierżawy, diety itp.). Wątpliwości rodzi także kwestia jednorazowych świadczeń uzyskiwanych na przykład z tytułu odszkodowania czy będących nagroda w różnych konkursach. Wydaje się, iż nie ma obowiązku sum tych wpisywać. Można je jednak podać, stanowiq one bowiem dochód. Dzięki ich wpisaniu nie pojawia się wątpliwości podczas analizy oświadczenia, zwłaszcza przy konfrontacji tej rubryki z rubryka dotyczaca zasobów pieniężnych. Podobnie rzecz się ma np. $z$ dietami radnych, których wysokość jest jawna. Każdy może więc uzyskać o nich informację. Umieszczenie diet w oświadczeniu ułatwia jego analizę. Niepodanie diet zostało przez większość analizujących oświadczenia uznane za nieprawidłowośćs.

Z pewnością omawiane świadczenie nie stanowi dochodu osiąganego ani z tytułu zatrudnienia, ani innej działalności zarobkowej. Zdaniem Autorki nie można go również określić jako dochodu z zajęcia, bowiem „zajęcie” to: czynność wykonywana przez kogoś, praca stanowiaca źródło utrzymania ${ }^{4}$. Literalna wykładnia tego pojęcia nie pozwala na zakwalifikowanie faktu otrzymywania świadczenia socjalnego jako „zajęcia”, co prowadzi do wniosku, że w pkt IX nie ma obowiązku wykazywania świadczenia 500+. Również w doktrynie zinterpre-

2 D. Bąbiak-Kowalska, Z. Majewski, A. Piskorz-Ryń, Jakie błędy popełniamy najczęściej?, http://www.wspolnota.org.pl/aktualnosci/aktualnosc/jakie-bledy-popelniamy-najczesciej/ [dostęp 29 marca 2018 r.].

3 Ibidem.

$4 \quad$ Http://sjp.pwn.pl/slowniki/zaj\%C4\%99cie.html [dostęp 29 marca 2018 r.]. 
towano przepis jako: źródła dochodu aktywnego, nie zaś np. zasiłki dla bezrobotnych czy świadczenia emerytalno-rentowe ${ }^{5}$.

Inaczej jednak stwierdził B. Lackoroński, uznając, że: uzyskiwane przez posła-elekta świadczenia rodzinne $w$ postaci świadczenia pielegnacyjnego oraz dodatku do zasiłku rodzinnego powinny być wykazane w punkcie IX Oświadczenia o stanie majątkowym jako „dochód z tytułu innych zajęć”. Odnotować jednak należy, że w opinii tej Autor przeanalizował powyższe świadczenia jedynie pod kątem dochodu, nie omawiając zaś w ogóle kwestii związanych z wątpliwościami dotyczącymi sformułowań użytych w pkt IX załącznika.

P. Uziębło z kolei wyraził opinię, że istnieje obowiązek ujawnienia przez posłów i senatorów wszystkich dochodów osiąganych w danym roku, bez względu na to, jaka jest podstawa prawna ich osiągnięcia. Ważne jest, że taka działalność ma charakter zarobkowy ${ }^{7}$. Jednocześnie Autor ten dodaje, że wskazane dochody powinny zostać ujęte w tożsamy sposób, jak dochody ujawniane w rocznym zeznaniu podatkowym, obejmując nie tyko dochody uzyskiwane w tytułu zatrudnienia na umowę o pracę, ale także prowadzenia działalności na podstawie umów cywilnoprawnych czy też z tytułu otrzymywania świadczeń społecznych. Pogląd ten (choć wyrażony zanim pojawiło się świadczenie 500+) potwierdza tezę, że dla potrzeb oświadczenia majątkowego świadczenie 500+ (będące dochodem), nie mając charakteru zarobkowego i będąc wolne od podatku dochodowego od osób fizycznych ${ }^{8}$, nie musi być wykazywane w pkt IX („Oświadczenia o stanie majątkowym”).

Charakter świadczenia wychowawczego wskazuje, że uzyskane kwoty nie muszą być wykazywane w pkt IX oświadczenia majątkowego, gdyż - chociaż stanowią dochód - nie jest on osiągany w związku z zatrudnieniem bądź inną działalnością zarobkową lub zajęciami. Kwota świadczenia powinna być jednak wykazana w pkt I „Zasoby pieniężne” w takim zakresie, w jakim nie została ona zużyta i przyczyniła się do powstania bądź powiększenia owych zasobów. Biorąc pod uwagę jednak obowiązek starannego i zupełnego wypełnienia każdej z rubryk oświadczenia, można uznać, że wpisanie otrzymanego świadczenia jest możliwe. Nie można wskazać ani wyraźnej podstawy prawnej w postaci prze-

5 Tak: I. Galińska-Rączy, Ujawnianie w punkcie IX oświadczenia o stanie majątkowym kwoty odszkodowania od przewoźnika lotniczego $z$ tytułu odwołania lotu [w:] Status posła w opiniach Biura Analiz Sejmowych (2007-2015), t. 2, cz. 2, red. I. Galińska-Rączy, Warszawa 2015, s. 260.

6 Idem, Opinia prawna z 5 listopada 2015 r. w sprawie uwzględniania w oświadczeniu majątkowym jako dochodu zasiłku i świadczenia pielegnacyjnego na niepetnosprawne dziecko oraz dodatków rodzinnych - pytanie Pana posła-elekta Wojciecha Bakuna, BAS-WAL-2297/15, niepubl.

7 P. Uziębło [w:] K. Grajewski, J. Stelina, P. Uziębło, Komentarz do ustawy o wykonywaniu mandatu posła i senatora, Warszawa 2014, s. 422.

8 Art. 33 ustawy o pomocy państwa w wychowywaniu dzieci w związku z art. 21 ust. 1 pkt 8 ustawy o podatku dochodowym od osób fizycznych. 
pisu ani rubryki wzoru oświadczenia, która nakazuje ujawnienie świadczenia tego rodzaju. Praktyka jednak wypełniania oświadczeń majątkowych wskazuje na rozszerzającą interpretację pojęcia „dochody uzyskiwane $\mathrm{z}$ innych zajęć”, co z kolei może prowadzić do wniosku, żeby z ostrożności wpisywać takie dochody, które - choć literalnie nie są dochodami „z zajęć” - to jednak stanowią dochód osoby zobowiązanej do złożenia oświadczenia o stanie majątkowym. Zgodzić się należy ze stanowiskiem J. Kulickiego: Nie będzie jednak błędem podanie tego rodzaju przychodów, np. $w$ czesści IX oświadczenia. Nie sa to co prawda ani dochody $z$ tytułu zatrudnienia, ani dochody z innej działalności zarobkowej (np. działalności wykonywanej osobiście) lub zajęć, jednak nic nie stoi na przeszkodzie aby uwzględnić je $w$ oświadczeniu majątkowym, szczególnie jeżeli miały one istotny wpływ na stan majątkowy parlamentarzysty. Nie będzie się to sprzeciwiało treści art. 35 ust. 1 ustawy [ustawy o wykonywaniu mandatu posła i senatora - dopisek J.M.K.], aczkolwiek będzie wychodziło poza katalog informacji przewidzianych we wzorze oświadczenia. Trzeba jednak pamiętać, że oświadczenie majątkowe poddawane jest analizie i kontroli zarówno w samym Sejmie lub Senacie (por. art. 35 ust. 6 ustawy), jak i przez Centralne Biuro Antykorupcyjne (por. art. 35 ust. 6 a ustawy) oraz organy podatkowe i kontroli skarbowej. W tym ostatnim przypadku przede wszystkim w zakresie kontroli źródeł pochodzenia majątku podatnika (por. np. art. 2 ust. 1 pkt 3 i art. 14a ustawy o kontroli skarbowej [powołana ustawa z 28 września 1991 r. o kontroli skarbowej (t.j. Dz.U. 2004, nr 8, poz. 65, ze zm.) została uchylona przez ustawę z 16 listopada 2016 r. - Przepisy wprowadzające ustawę o Krajowej Administracji Skarbowej, Dz.U. poz. 1948, ze zm. - uwaga J.M.K.]. Pominięcie w oświadczeniu majątkowym części przychodów i dochodów przez parlamentarzystę (oczywiście tych nie znajdujących swojego odzwierciedlenia $w$ ustawowym wzorze oświadczenia) może powodować konieczność złożenia wyjaśnień podmiotom uprawnionym do analizy i kontroli tych oświadczeń 9 .

2. W przypadku alimentów należy odróżnić, czy są to alimenty świadczone, czy też otrzymywane.

W pierwszym przypadku należy zwrócić uwagę, że obowiązek alimentacyjny to obowiązek dostarczania środków utrzymania, a w miarę potrzeby także środków wychowania (art. 128 k.r.o.). Stosunek alimentacyjny i wynikający z niego obowiązek alimentacyjny (roszczenie) jest oparty na modelu zobowiązaniowym. Strony stosunku prawnego alimentacyjnego, tj. uprawnionego i zobowiązanego, nazywa się także - odpowiednio, wierzycielem i dłużnikiem alimentacyjnym ${ }^{10}$.

9 J. Kulicki, Zamieszczanie w oświadczeniu majątkowym informacji o zwrocie podatku VAT, odszkodowaniu z zakładu ubezpieczeń oraz spadku [w:] Status posła w opiniach Biura Analiz Sejmowych (2007-2015), t. 2, cz. 2, red. I. Galińska-Rączy, Warszawa 2015, s. 262.

10 G. Jędrejek, Kodeks rodzinny i opiekuńczy. Pokrewieństwo i powinowactwo, komentarz do art. 61(7)-144(1), 2014, LEX. 
Pogląd o zobowiązaniowym charakterze stosunku alimentacyjnego został przyjęty w orzecznictwie. W uzasadnieniu uchwały 24 lutego 2011 r., sygn. III CZP 134/10, Sąd Najwyższy stwierdził m.in: Konkretny obowiązek alimentacyjny powstaje $w$ razie spełnienia się ustawowych przesłanek alimentacji. $W$ ramach tego stosunku zobowiązaniowego między określonymi indywidualnie osobami, uprawnionemu przysługuje roszczenie o alimenty (wierzytelność), a zobowiązany - dłużnik ma obowiązek spetnić odpowiadające świadczenie alimentacyjne $(d \nmid u g)^{11}$. W uzasadnieniu uchwały 7 sędziów z 24 maja 1990 r., sygn. III CZP 21/90, Sąd Najwyższy stwierdził m.in.: Obowiązek alimentacyjny należy do kategorii stosunków obligacyjnych, a ze względu na swe źródło należy do zobowiązań prawnorodzinnych ${ }^{12}$.

Zgodnie $\mathrm{z}$ art. $133 \$ 1$ k.r.o. rodzice obowiązani są do świadczeń alimentacyjnych względem dziecka, które nie jest jeszcze w stanie utrzymać się samodzielnie, chyba że dochody z majątku dziecka wystarczają na pokrycie kosztów jego utrzymania i wychowania. Rodzice mogą uchylić się od świadczeń alimentacyjnych względem dziecka pełnoletniego, jeżeli są one połączone z nadmiernym dla nich uszczerbkiem lub jeżeli dziecko nie dokłada starań w celu uzyskania możności samodzielnego utrzymania się (art. $133 \$ 3$ k.r.o.).

Zgodnie z art. 35 ust. 1 u.w.m.p.s. posłowie są obowiązani do złożenia oświadczenia o swoim stanie majątkowym. Oświadczenie to zawiera w szczególności informacje o zobowiązaniach pieniężnych o wartości powyżej 10000 złotych, w tym zaciągniętych kredytach i pożyczkach oraz warunkach, na jakich zostały udzielone (art. 35 ust. 1 pkt 4 u.w.m.p.s. oraz pkt XI wzoru oświadczenia).

Wykładnia celowościowa art. 35 ust. 1 pkt 4 u.w.m.p.s. prowadzi do wniosku, że: chodzi o każde jednostkowe zobowiazanie, którego wartość przekracza wskazana $w$ art. 35 ust. 1 pkt 4 ustawy kwote. W sytuacji, kiedy poseł posiada kilka zobowiązań wobec tej samej osoby, a ich suma przekracza wskazana wyżej kwote, powinien ujawnić ten fakt, mimo że wartość jednostkowa poszczególnych zobowiazań jest niższa od tej kwoty ${ }^{13}$.

Taką samą interpretację należy zastosować w przypadku świadczeń okresowych, do których zalicza się świadczenia alimentacyjne. Ponieważ przepis art. 35 ust. 1 pkt 4 u.w.m.p.s. nakazuje ujawniać zobowiązania pieniężne - to świadczenia alimentacyjne względem byłego małżonka ${ }^{14}$, dzieci (zarówno małolet-

11 LEX nr 707477.

12 OSNCP 1990, nr 10-11, poz. 12.

13 Tak. I. Galińska-Rączy, Ujawnienie w oświadczeniu o stanie majątkowym informacji odnoszacych się do zobowiązań posła (w tym danych współkredytobiorców) [w:] Status posła w opiniach Biura Analiz Sejmowych (2007-2015), t. 2, cz. 2, red. I. Galińska-Rączy, Warszawa 2015, s. 255.

14 Art. $60 \$ 1$ k.r.o: Małżonek rozwiedziony, który nie został uznany za wyłacznie winnego rozkładu pożycia i który znajduje się w niedostatku, może żądać od drugiego małżonka rozwiedzionego dostarczania środków utrzymania w zakresie odpowiadającym uspra- 
nich, jak i pełnoletnich ${ }^{15}$ ), a także ewentualnie innych krewnych ${ }^{16}$ winny zostać ujawnione w pkt XI oświadczenia o stanie majątkowym. Kryterium istotnym jest wartość zobowiązania powyżej 10000 złotych, liczonego w stosunku rocznym, oddzielnie dla każdej osoby

W przypadku natomiast alimentów otrzymywanych należy przypomnieć, że zgodnie z art. $133 \$ 1$ k.r.o. rodzice obowiązani są do świadczeń alimentacyjnych względem dziecka, które nie jest jeszcze w stanie utrzymać się samodzielnie, chyba że dochody z majątku dziecka wystarczają na pokrycie kosztów jego utrzymania i wychowania. Alimenty wypłacane na dzieci nie podlegają opodatkowaniu podatkiem dochodowym od osób fizycznych.

Alimenty zasądzone na dziecko należy potraktować podobnie jak omówione wcześniej świadczenie 500+. Zdaniem Autorki opinii nie ma uzasadnienia dla wykazywania otrzymywanych alimentów na dziecko w pkt IX „Dochody osiągane z tytułu zatrudnienia lub innej działalności zarobkowej lub zajęć, z podaniem kwot uzyskiwanych z każdego tytułu”. Zostaną one natomiast zapewne wykazane w sposób pośredni - w pkt I „Zasoby pieniężne”, jeśli nadal znajdują się w tych zasobach. Jeśli kwoty te nie zostały bowiem wydatkowane, powiększą posiadane zasoby pieniężne posła.

3. Dochód z najmu lokalu mieszkalnego za cały okres należy ujawnić w oświadczeniu o staniu majątkowym, gdyż jest to dochód z „zajęcia” (o czym była już

wiedliwionym potrzebom uprawnionego oraz możliwościom zarobkowym i majątkowym zobowiąanego.

$\$$ 2. Jeżeli jeden $z$ małżonków został uznany za wyłącznie winnego rozkładu pożycia, a rozwód pociaga za soba istotne pogorszenie sytuacji materialnej matżonka niewinnego, sąd na żądanie małżonka niewinnego może orzec, że małżonek wyłacznie winny obowiązany jest przyczyniać się w odpowiednim zakresie do zaspokajania usprawiedliwionych potrzeb małżonka niewinnego, chociażby ten nie znajdował się w niedostatku.

\$3. Obowiązek dostarczania środków utrzymania matżonkowi rozwiedzionemu wygasa $w$ razie zawarcia przez tego małżonka nowego matżeństwa. Jednakże gdy zobowiązanym jest małżonek rozwiedziony, który nie został uznany za winnego rozkładu pożycia, obowiązek ten wygasa także $z$ uptywem pięciu lat od orzeczenia rozwodu, chyba że ze względu na wyjątkowe okoliczności sąd, na żądanie uprawnionego, przedłuży wymieniony termin pięcioletni.

15 Zgodnie $\mathrm{z}$ art. $58 \$ 1 \mathrm{w}$ wyroku orzekającym rozwód sąd orzeka, w jakiej wysokości każdy z małżonków jest obowiązany do ponoszenia kosztów utrzymania i wychowania dziecka.

16 Art. 128 k.r.o: Obowiązek dostarczania środków utrzymania, a w miarę potrzeby także środków wychowania (obowiązek alimentacyjny) obciąża krewnych $w$ linii prostej oraz rodzeństwo. Art. $129 \$ 1$ k.r.o: Obowiązek alimentacyjny obciąża zstępnych przed wstępnymi, a wstępnych przed rodzeństwem; jeżeli jest kilku zstępnych lub wstępnych obciąza bliżsych stopniem przed dalszymi.

\$ 2. Krewnych $w$ tym samym stopniu obciąża obowiązek alimentacyjny w częściach odpowiadających ich możliwościom zarobkowym i majątkowym. 
mowa). Jak wskazuje P. Uziębło obowiązek ujawnienia dochodów z tytułu zatrudnienia lub innej działalności zarobkowej lub zajęć dotyczy wszystkich dochodów, które parlamentarzysta osiąga w danym roku, jeśli działalność ma charakter zarobkowy, to wskazane dochody powinny zostać ujęte w tożsamy sposób jak dochody ujawniane w rocznym zeznaniu podatkowym. Wspomniana działalność zarobkowa nie musi w żadnym wypadku stanowić działalności gospodarczej ${ }^{17}$.

Dochód z najmu mieszkania, jeśli nie jest to najem w ramach prowadzonej działalności gospodarczej, należy wykazać w oświadczeniu o stanie majątkowym w pkt IX jako „Inne dochody osiągane z tytułu zatrudnienia lub innej działalności zarobkowej lub zajęć, z podaniem kwot uzyskiwanych z każdego tytułu”. Jeśli natomiast najem wykonywany jest w ramach działalności gospodarczej posła, dochód z tego tytułu należałoby wykazać w pkt VII oświadczenia o stanie majątkowym, w którym wpisywane są dochody za ubiegły rok osiągnięte z tytułu prowadzenia działalności gospodarczej ${ }^{18}$.

4. Kaucja zabezpieczająca dotycząca umów najmu uregulowana jest w ustawie z 21 czerwca 2001 r. o ochronie praw lokatorów, mieszkaniowym zasobie gminy i o zmianie Kodeksu cywilnego ${ }^{19}$. Zgodnie z art. 19a ust. 4 i 5 zawarcie umowy najmu okazjonalnego lokalu może być uzależnione od wpłacenia przez najemcę kaucji zabezpieczającej pokrycie należności z tytułu najmu okazjonalnego lokalu przysługujących właścicielowi w dniu opróżnienia lokalu oraz ewentualnych kosztów egzekucji obowiązku opróżnienia lokalu. Kaucja nie może przekraczać sześciokrotności miesięcznego czynszu za dany lokal, obliczonego według stawki czynszu obowiązującej w dniu zawarcia umowy najmu okazjonalnego lokalu. Kaucja podlega zwrotowi w ciągu miesiąca od dnia opróżnienia lokalu, po potrąceniu należności właściciela. Jak wskazał Sąd Apelacyjny w Warszawie w wyroku z 26 lutego 2014 r., sygn. akt VI A Ca 1117/13, umowa kaucji gwarancyjnej jest umową nienazwaną, dwustronnie zobowiązującą, kauzalną, mocą której: jedna ze strona przenosi na własność drugiej strony stosunku określona ilość pieniędzy albo rzeczy rodzajowo oznaczonych celem zabezpieczenia ewentualnych roszczeń, jakie moga powstać z innego istniejącego między stronami stosunku prawnego, natomiast druga strona zobowiązuje się po ustaniu tego stosunku prawnego zwrócić taka sama ilość pieniędzy albo taką sama ilość rzeczy, tego samego gatunku i tej samej jakości, z tym jednak zastrzeżeniem, że obowiązek zwrotu kaucji gwarancyjnej nie istnieje w zakresie niezaspokojonej wierzytelności objętej zabezpieczeniem ${ }^{20}$.

17 P. Uziębło [w:] K. Grajewski, J . Stelina, P. Uziębło, Komentarz do ustawy, op. cit., s. 422.

18 E. Wojnarska-Krajewska, Informacja prawna z dnia 12 listopada 2015 r. dotycząca kwestii związanych $z$ oświadczeniem majątkowym, BAS-WAL 2316/15, niepubl.

19 Pomijam w tym miejscu kaucję wynikającą $\mathrm{z}$ art. 6 tej ustawy, dotyczącą gospodarowania mieszkaniowym zasobem gminy.

20 Http://orzeczenia.waw.sa.gov.pl/content/\$N/154500000003003_VI_ACa_001117_ 2013_Uz_2014-02-26_002 [dostęp 29 marca 2018 r.]. 
W świetle powyższego, biorąc pod uwagę sankcję, jaką określono w art. 35 ust. 9 u.w.m.p.s., a mianowicie, że podanie nieprawdy lub zatajenie prawdy w oświadczeniu o stanie majątkowym powoduje odpowiedzialność na podstawie art. 233 $\$ 1$ Kodeksu karnego ${ }^{21}$, wydaje się, iż z ostrożności należałoby kaucję umieścić w oświadczeniu majątkowym, z tym, że - jak się wydaje - nie w pkt IX oświadczenia („Dochód z zajęcia”), a raczej w pkt I, czyli w „Zasobach pieniężnych”.

\section{Podsumowanie}

- Istnieją rozbieżności w doktrynie co do pojęcia użytego w art. 35 ust. 1 pkt 2 u.w.m.p.s. „dochody osiągane z tytułu zatrudnienia lub innej działalności zarobkowej lub zajęć”. Literalna wykładnia tego pojęcia nie pozwala na zakwalifikowanie faktu otrzymywania świadczenia socjalnego jako „zatrudnienia”, „działalności zarobkowej” ani „zajęcia”.

- Praktyka co do oświadczeń majątkowych wskazuje na rozszerzającą interpretację omawianego pojęcia. Zdaniem Autorki opinii nie znajduje ona oparcia w przepisach.

- Nie ma podstawy prawnej dla obowiązku bezpośredniego wykazywania świadczenia 500+ bądź alimentów zasądzonych na dziecko jako „dochodów osiąganych z tytułu zatrudnienia lub innej działalności zarobkowej lub zajęć”. Jednak ich wykazanie nie jest zakazane. Zostaną one ponadto ewentualnie wykazane w sposób pośredni w „Zasobach pieniężnych”, o ile powiększyły te zasoby i nie zostały zużyte, bez możliwości identyfikacji ich pochodzenia.

- Świadczenia alimentacyjne względem byłego małżonka, dzieci (zarówno małoletnich, jak i pełnoletnich), a także ewentualnie innych krewnych powinny zostać ujawnione w pkt XI oświadczenia o stanie majątkowym. Kryterium istotnym jest wartość zobowiązania powyżej 10000 złotych, liczonego w stosunku rocznym, oddzielnie dla każdej osoby.

- Dochód z najmu lokalu mieszkalnego - jeśli nie jest to najem prowadzony w ramach działalności gospodarczej - powinien być zakwalifikowany jako „zajęcie” dla potrzeb oświadczenia o stanie majątkowym. Należy go wykazać w oświadczeniu o stanie majątkowym w pkt IX jako „Inne dochody osiągane z tytułu zatrudnienia lub innej działalności zarobkowej lub zajęć, z podaniem kwot uzyskiwanych z każdego tytułu”. Jeśli natomiast najem wykonywany jest w ramach działalności gospodarczej posła, dochód z tego tytułu należy wykazać w pkt VII oświadczenia o stanie majątkowym, w którym wpisywane są dochody za ubiegły rok osiągnięte z tytułu prowadzenia działalności gospodarczej.

${ }^{21}$ Art. $233 \$ 1$. Kto, składając zeznanie mające stużyć za dowód w postępowaniu sądowym lub $w$ innym postępowaniu prowadzonym na podstawie ustawy, zeznaje nieprawdę lub zataja prawdę, podlega karze pozbawienia wolności od 6 miesięcy do lat 8. 


\section{Bibliografia}

Bąbiak-Kowalska D., Majewski Z., Piskorz-Ryń A., Jakie błędy popetniamy najczęściej?, http://www.wspolnota.org.pl/aktualnosci/aktualnosc/jakie-bledy-popelniamy-najczesciej/.

Galińska-Rączy I., Ujawnianie w punkcie IX oświadczenia o stanie majątkowym kwoty odszkodowania od przewoźnika lotniczego z tytułu odwołania lotu [w:] Status posła w opiniach Biura Analiz Sejmowych (2007-2015), t. 2, cz. 2, red. I. Galińska-Rączy, Warszawa 2015.

Galińska-Rączy I., Ujawnienie w oświadczeniu o stanie majątkowym informacji odnoszacych się do zobowiązań posła (w tym danych współkredytobiorców) [w:] Status posła w opiniach Biura Analiz Sejmowych (2007-2015), t. 2, cz. 2, red. I. Galińska-Rączy, Warszawa 2015.

Jędrejek G., Kodeks rodzinny i opiekuńczy. Pokrewieństwo i powinowactwo, komentarz do art. 61(7)-144(1), 2014, LEX.

Kulicki J., Zamieszczanie w oświadczeniu majątkowym informacji o zwrocie podatku VAT, odszkodowaniu z zakładu ubezpieczeń oraz spadku [w:] Status posła w opiniach Biura Analiz Sejmowych (2007-2015), t. 2, cz. 2, red. I. Galińska-Rączy, Warszawa 2015.

Uziębło P. [w:] K. Grajewski, J. Stelina, P. Uziębło, Komentarz do ustawy o wykonywaniu mandatu posta i senatora, Warszawa 2014. 